\title{
Sotaques: Style and Ethnicity in a Brazilian Folk Drama
}

\section{Kazadi wa Mukuna}

Since its first presentation in the eighteenth century (ca. 1780) during the so-called "Civilização de Couro" period when the cattle raising was at its peak in Brazil, Bumba-meu-Boi continues to evolve, in spite of persecution by those in authority, by adapting to changes in social fabrics. My presentation argues that Bumbameu-Boi was created by the African slave in colonial Brazil. This assertion is sustained by several facts, primarily, the function for which the drama was created, to serve as a vehicle of social control used to denounce and to ridicule slave owners during colonial Brazil. Other styles which came into existence at later periods were created by other races of the population in imitation of the African by maintaining the story line of the play and its dramatization without necessarily adhering to the original raison d'être. Each of the new styles incorporated features which reflected its ethnic identity. The Argument for African authorship of the Bumba-meuBoi is also sustained by the chronology of appearences of the styles: the African style called Boi de Zabumba, the Indian style known as the Boi de Matraca introduced in Maranhão in 1868, and the most recent style called Boi de Orquestra (1958) with strong European influence, and by musical instruments, rhythmic organization, costumes, and the format of dance presentation. With the changing of time, modifications such as the religious overtone and shift in the application social control focussed on the community as a whole became vital insertions to the survival of the Bumbameu-Boi, as its original functions became obsolete. 


\section{A. Definition and Origin}

For decades, the quest for the origin of cultural practices had become a major obsession among students of Brazilian culture, who concentrated most of their effort on this issue to the point of ignoring other pertinent aspects of cultural analysis. Often, those caught in this web of intellectual exercise were induced into error and tended to confuse the principles of creation with those of innovation. To believe that all existing cultural practices in a society, such as Brazil, originated other societies with which contacts were made or from which members came is not only absurd but it fosters an archaic theory by the diffusionist extremists that all cultural practices originated from one group in one area of the world, and that their dissemination is due to contacts made possible by the rise of navigation (1). To believe the contrary, diffusionists would argue, is to perpetuate the isolation of societies.

In recent decades the formulation of theories concerning the scrutiny of Africanism in the music of Latin America and the Caribbean has become an urgent priority on the agendas of individual researchers and institutions. Their efforts have resulted in the suggestion of a variety of methodological guidelines which differ in expression but agree on the value of considering the conceptual level of the carriers of cultural material, as affected by the history of the new society, in order to grasp a deeper undertanding of the persistence and continuity of African cultural elements in the musical fabrics in the New World ${ }^{(2)}$. Expanding this idea, the Grupo de Trabajo asserts:

"The identification of African elements in the musical fabric of Latin America should also take into consideration the historical aspect which includes the impact of all phenomena, social and economic, on the carriers of the cultural material. This sustains the fact that a musical expression is indeed a product of the influence of these phenomena on the conceptual level of its makers. To the latter, music is not conceived as mere organization of sounds, but rather as integral parts of a total expression, which include langua- 
ges, dances movements, games, and special behaviours, pertaining to a dynamic society." (3)

Implicit in this methodological concept are the three focusses of interpretation, each of which requires a precise analysis of historical, cultural, and conceptual proceses of evolution of Africanisms in the Americas. These are: a) persistence/continuity; b) innovation/transformation; c) creation/concept. In the first category one seeks for resilience of physical materials (musical instruments, rhythmic patterns, dance steps, cultural manifestation, religious practice, etc.) which have been maintained in the New World. In the second, African musical/cultural elements have been modified morphologically or re-interpreted conceptually in the new society. In the last aspect there is an abcense of physical African elements, but the new musical/cultural expression is structured according to the African principles of organization. Discussing Africanisms in African-American Music, Portia Maultsby concludes:

"A study of African- American music from the seventeenth through the twentieth centuries reveals that African retentions in African-American music can be defined as a core of conceptual approaches. Fundamental to these approaches is the axion that music-making is conceived as a communal/participatory group activity. Black people create, interpret, and experience music out of an African frame of reference - one that shapes musical sound, interpretation, and behavior and makes black music traditions throughout the world a unified whole." ${ }^{(4)}$

It is within the framework of these methodological guidelines that the argument about the Africanism in the Bumba-meu-Boi in Maranhão is formulated, seeking for evidence of the principles of organization of musical expression which continue to perpetuate the Africanism in the diaspora, and identifying where possible traces in musical instruments, dance steps, etc.

An examination of the existing literature dealing with the origin of the Bumba-meu-Boi reveals some conflicting theories. The first of these advanced by Guilheme Theodoro Pereira de 
Melo (1908) attributes the origin of Bumba-meu-Boi to Portugal and affirms that it is a variation of sixteenth century play Monólogo do Vaqueiro (The Cowboy Monologue), presented by its author, Gil Vicente on June 8, 1502, on the occasion of the birth of Prince Dom João, King Dom Manuel's first born ${ }^{(5)}$. In Brazil this theory is given credence in Bahia and Pernambuco where Bumba-meuBoi is associated with Christmas. According to M. I. Pereira de Queiroz, Bumba-meu-Boi is part of Reisados celebrated during the Epiphany (January 6), composed of short sketches whose story revolves around the ox. She writes:

"The small drama which is now being presented probably originated in Portugal. During ancient religious processions in this country burlesque characters paraded intermingled with saints and angels... In Brazil, the ox of precessions and of ancient bull races in Portugal had transformed itself into the principal character of a dramatic dance..."

The second theory formulated by Arthur Ramos (1954) dismisses de Melo's suggestion and indicates that Bumba-meu-Boi has three origins: African, Ameridian, and European. Discussing the African origin Ramos argues that Bumba-meu-Boi contains totemic survivals from Africa. He states:

"It won"t be necessary to insist too much on the meaning of popular feasts of totemic origin... Recall that psycho-analytically the totemic animal is the symbol of the Father... But, it is in the Bumba-meu-Boi that the totemic complexes reveal themselves with more evidence... In this manifestation, the death of the ox is the leit-motif. The African black kept these ritual feasts i his subconscious and, through the principle of repetition, expended them periodically in popular manifestations which he encountered in the new home." ( 7 )

The third theory suggested by Domingos Vieira Filho asserts tha Bumba-meu-Boi was born in the Portuguese colony (Brazil), as a logical happening of colonial formation, with influence of the three races which forged the nationality ${ }^{(8)}$. The choice of the ox for the drama, concludes Vieira Filho, was made by the African 
slave because "... the negro slave was the ox"s brother in suffering and in work".

I concur with the third theory not for the reasons advanced by its author. As conceived and celebrated in Brazil, Bumba-meu-Boi can be defined as a folk drama with music and dance which reflects an image of interaction among social classes in colonial Brazil. In a more precise terms, Bumba-meu-Boi was a collective statement of retaliation voiced by the opressed members of the society to denounce and ridicule their opressors. It reflects character and structure different from its alleged prototypes. It is both a social/secular and psychological/religious, as well as collective and personal manifestation sustained by the complex nature of its objectives. While Bumba-meu-Boi allows participants to exteriorize aggressions through hilarious displays of social sanctions, today, it also provides them with an opportunity to express profound devotion to Saint John, Saint Peter, and Saint Marçal.

As a collective and social manifestation, a presentation of the Bumba-meu-Boi is an occasion for communal merrymaking. As a personal and religious expression, it has become a personal affair during which individuals participate to keep private promises made to the Saints and to renew their covenants with them. The ox, symbol of power and wealth during the Leather Civilization is utilized in the drama to serve as the catalyst for deep seated satire against the ruling class. It is only with time the ox became object of devotion which is adorned, sanctified through baptism, and sacrificed to Saint John to serve as a link of covenant between the saints and the participants.

Subtle satire is incorporated into the roles of characters representing social authorities and into the manner in which these authorities are addressed in the play by those considered to be of the lowest order in the social hierarchy. Ridiculed characters vary from one region to another, but the most prominent in Maranhão are the Priest, the Portuguese Master (Amo), and the Captain (Cavalo Marinho) who represent the ruling class and slave owners in colonial Brazil. 
In order to gain a better understanding of the origin and the definition of the Bumba-meu-Boi let us observe the legend that provides the story line for the drama. In this legend there is the presence of three racial groups and two social classes. The Portuguese Amo, owner of the ranch on which the story unfolds, the Priest, and the Capitão, represent the ruling class; Pai Francisco, the daring African slave, the Indian medicine-man, the cowboys, and the servants represent the lower class. The interaction among these social classes and racial groups is triggerd by the impact of the chain of events and the intervention of each racial character in the resolution and the restoration of social harmony. The following version of the legend was recorded during my 1980-1981 field trips in the district of Pindaré located $250 \mathrm{~km}$ south of São Luís, the capital of the state of Maranhão:

"On a ranch owned by a Portuguese Master (known in the plays as Amo) and his wife Dona Maria, dwelt the slave Francisco (also called Nego Chico), his pregnant wife (Mãe Catirina), and other slaves. The Amo has a favorite ox, referred to in the legend as "Boi Estrela" (the Star Ox), 'Fama Real' (Royal Fame). One day, Mãe Catirina has an urge to eat of an ox's tongue. Making her desire known to her husband, Mãe Catirina specifies that the tongue must be that of the master's favorite animal. Concerned for the life os his unborn child, Pai Francisco leads the ox into the woods, where he kills it and takes the tongue to his wife, who cooks and eats it. The next day, the Amo realizing that his favorite ox is missing, summons all cowboys and slaves together to ask if anyone has seen it. One of them informs him that he had seen Pai Francisco taking the "Star Ox" into the woods, from whence minutes later a gunshot was heard. Searching the woods, they encounter the remains of the ox. Infuriated by the sight of his dead animal, the Amo orders the Director of Indians to arrest Pai Francisco. Before undertaking such a dangerous mission, the Director of Indians seeks blessing from the priest. Adressing Pai Francisco, the Amo orders him to bring his ox back to life or die 
himself. A Portuguese doctor enters the scene and makes several attempts to resurrect the $o x$ by in vein. Finally a shaman (Indian medicine-man) is summoned. He lays his hands on the animal which arises, and they all dance joyfully through the night." (10)

\section{B - Authorship}

From the sociological point of view,Bumba-meu-Boi is a vehicle for direct social control, utilized primarly by the opressed members of the society, and as a means of challenging the authority of the ruling class. Closer examination of the essence of the play reveals that, having no other recourse for revendication of their rights, the opressed members of the society created a play in which despised authorities are caricatured and denounced. The objective of the drama, then, is the denouncement of the ill-behaved members of the ruling class and the carrying out of deep-seated satire of them and all slave owners in a comical fashion.

Starting with Mãe Catirina's unreasonable request and Pai Francisco's daring compliance with it, every scene of the drama depicts ridicule of the authorities in one form or another. The killing of the master's favorite ox is indeed an act of provocation of his anger. But the adopted solution to pacify the situation reflects lower class" mockery of the white man's medicine. In the play the Portuguese doctor's attempts to ressurect the ox fail, but it is the Indian shaman's magic which succeeds in bringing the ox back to life. In the light of this interpretation which reveals the hidden satirical pun embedded in the two most significant contrasting episodes - provocation and pacification; tension and resolution -, of the entire drama, it can be deduced that Bumba-meu-Boi was created to serve as a manifestation of challenge of social injustices as seen by its author.

Addressing the question of authorship on the Bumba-meuBoi in a round table debate held in Maranhão (July 1986), Américo focuses on the inner structure of the play and states: 
"It is evident that Bumba-meu-Boi has a learned origin. This origin is implanted in the catequism cycle of the Jesuites who took advantage of the amusement which was also educational. It contains a moral lesson while at the same time it has all the characteristics of a theatrical piece."

I share Jomar Moraes" point of view when he asserts that external aspects of the tourinha and other European happenings of the ox are not sufficient to determine that our Bumba-meu-Boi comes from them. "I believe", he concludes, "our Boi has a popular origin, it is of the people".

The Brazilian origin of the Bumba-meu-Boi has been established above and is no longer an issue for debate. However, there is conclusive evidence which indicates that this folk drama could not have originated among the ruling class, but rather it is a creation of the lower class. In this lower class, it is certain that the African slave who was considered unhuman, and had to be enslaved to protect the Indian whose soul was being saved by the Jesuits, would be more likely than the latter to have come up with such an expression resulting from the conditions of his daily interaction with members of the ruling class. Describing Bumba-meu-Boi in 1840, Padre Lopes Gama also provides us with the ethnic identity of the first performer and author the drama. "Of so many popular diversions, frolics, and amusements that exist in our Pernambuco", writes Padre Lopes Gama, "I do not know one so foolish, so stupid, and insipid, as the incidentally well known Bumba-meu-Boi... A Negro hidden inside a shaggy fabric made of wool is the ox..." (12) Further evidence of the slave authorship of the Bumba-meu-Boi is encountered in the statement by an author who called himself "A Friend of Civilization" requesting that the performance of the Bumba-meu-Boi be abolished.

"When a large portion of the population takes upon itself to end with those firecrackers for being deadly, an authorization is granted to the stupid and immoral merrymaking of slaves called Bumba-meu-Boi." (13) 
It is not the symbolic death and the resurrection of the ox which constitute the essence of the Bumba-meu-Boi; it is the function for which it was conceived - to be the vehicle of retaliatory expression of the lower social class. As such Bumba-meu-Boi could only have been created in Brazil by those for whom this purpose had to be served. In the course of time, the basic structure of the drama was expanded to meet new social needs which included but were not limited to the criticism of the ruling class.

Within the drama itself one can still find sufficient evidence which indicates that Bumba-meu-Boi was created by the African slave. First, there is the identification of the daring slave and his wife by names - Pai Francisco and Màe Catirina. Second, the choice of the mode of delivery of satire through singing. This form of dramatization of satire when addressed to a superior is a widely spread practice among African cultures. "In song", writes Alan Merriam, "the individual or the group can express deep-seated feelings not permissibly verbalized in other contexts" ${ }^{\prime 14}$. Similar practice is aldo common place among the Bashi in Zaire, the Luo in Kenya, and Zulu in South Africa, to name just a few. The "Omangbetu Olya" of the Mangbetu people in the North East of Zaire, for example, is a repertoir of court songs that are sung to the King by his subjects and members of the court to indicate a problem, make a request, criticize him, or simply ask for drinks. Discussing similar practice among the Chopi of Mozambique, Hugh Tracey writes: "You can say publicly in songs what you cannot say privately to a man's face", and concludes, "and so this is one of the ways African society takes to maintain a spiritually healthy community" ${ }^{(15)}$. It is only through this genre of songs that subtle satires can be addressed to the King without fear of losing one's head. In Bumba-meu-Boi satire to members of the ruling class were delivered within this African concept.

\section{C - Sotques/Styles and Ethnicity}

"Sotaque" is a generic term used to distinguish the variety of styles of Bumba-meu-Boi in Maranhào and Piaui. There are three 
major styles each of which reflects characteristics peculiar to each of the racial groups which compose the Brazilian population: African, Indian, European. These peculiarities are apparent in the choice of musical instruments, costumes design, rhythmic patterns, and dance choreography. The coexistence of the three Bumba-meu-Boi styles in Maranhão began in 1958. The testimony recorded in the field and from written documents attest to the fact that the first Boi de Zabumba was the first style to be identified in Maranhão. "The first bois on the Island (São Luís), "writes Cyro Falcão, "were called De-Zabumba-Tambor. Their history developed alongside the drum implanted here by the African" ${ }^{(16)}$. With time, this style became also identified with the district of Guimarães, once a major slave center, thus giving rise to the expression Boi de Guimarães.

In 1861 the celebration of the Bumba-meu-Boi was prohibited state wide and in 1868 it reappeared. João Domingos Pereira do Sacramento writes: "In this year's frolic they introduced the Matracas sound with the accompaniment of dull shouts and dissonant which shivered bodies to hear them, without a minimum recallection of such things haveing been sued in Bumba-meu-Boi."

Boi de Orquestra, the newest of the three styles and the only one for which all circumstances of its creation are documented, was founded in 1958 by Mr. Francisco Paiva, leader of a brass ensemble in the Axixa district. The orchestra style came into being when Mr. Paiva and his musicians were accompanying a local Bumba-meu-Boi group in the street after their rehearsal.

When and where Bumba-meu-Boi was first performed remains unknown. However, available written documents from the past point to the $17^{\text {th }}$ and $18^{\text {th }}$ century sugar mills and plantations of Bahia and Pernambuco as the period and the sites of the first setting. José de Jesus Santos writes:

"The fact is that the seventeenth and eighteenth centuries witnessed the coming up of Bumba-meu-Boi, for this was the golden period of the cattle cycle in Northeast, North and South, 
when the lives of the inhabitants of these regions were profoundly interrelated to the cattle raising."

The dissemination of Bumba-meu-Boi in Brazil did not occur simultaneously with the expansion of cattle raising, although it did follow the same paths. From the valley of the São Francisco River, the site of the earliest mention of the merrymaking, Bumba-meuBoi followed the cattle into the states of Ceará, Piaui, Maranhão and Pará. Dişcussing the introduction of the Boi in Maranhão Cyro Falcão dates the first rehearsal to have occured during the tangerine expansion period, which corresponded with the 1838-46 uprising in the interior of the state, known as the Balaiada War (19). Domingos Vieira Filho also writes:

"Bumba-meu-Boi represents a remainder of the pastoral phase in the colony during which the ox was the important economic agent, driving herds of cattle in the vast pastures of the country's inland, implanting ranches and corrals which were often the initial nucleus of the important settlements. ${ }^{\prime \prime}(20)$

"In Maranhão", concludes Vieira Filho, "Bumba-meu-Boi

- dates from the latter years of the eighteenth century as merrymaking for slaves on ranches and sugar mills" ${ }^{(21)}$. In 1858, the Maranhão newspaper, $O$ Globo published an article qualifying Bumba-meu-Boi indecent, barbarous, grotesque and worthy of being banned.

\section{1. Instrumentation}

The instrumentation of the Boi de Zabumba style is composed primarily of percussive musical instruments. The principal instrument, the zabumba (Photo 1), is a cylindrical, double-headed drum with ox or goat skin on both heads. Originally the body of this drum was made from a carved tree trunk or from ply-wood. Today metallic barrels are being substituted for these materials. In its original form, the skin heads were attached to the body of the instrument by wooden rings, and in the more modern version, these wooden rings are replaced by metallic ones. 
The zabumba is played in a fixed location, with the weight of the instrument resting on a peg (Photo 2). During the procession, the zabumba is hund on a stick and carried on the shoulders of two people while the third plays it freely.

The origin of this instrument and its association with Bumba-meu-Boi are still unknown. However, despite the lack of supporting evidence, there is speculation attributing the Zabumba to Africa. Similar assertions about remnants of African cultural traits in Brazil have been judged very misleading, and should be dismissed for failing to specify the African cultural area of the alleged origin, and for failing to provide us with insights about changes which might have occured during a given period of time, leading to the attained structures, functions, and forms of expression in the new milieu with which the element is associated. The ambiguity surrounding the origin of the Zabumba stems from its name and its morphologic structure. On the one hand the structure of its modern version resembles that of bass drum in the European music tradition. But what must be kept in mind is that this new version derives from a process of substitution of construction materials. On the other hand the original structure of Zabumba is more closely related to the array of double-headed drums encountered in several West African cultures. In Nigeria, for example, there is the Atete drum (Illustration 1) from Ogun State, which is udes for worship of Orisha during Egungun festivals. This drum is used also during social gatherings ${ }^{(22)}$.

The Zabumba varies in size, ranging between sixty to eighty centimeters in diameter and thirty to forty centimeters in depth. The body is painted in solid colors or adorned with geometric figures and other decorative motifs. Tuning is accomplished by tightening the rope holding the two rings around the drum heads. The number of Zabumba drums in an ensemble is unlimited. They provide heavy straight beats and their variations similar to those of the Tambor de Crioulo of African practiced in the region. The Africanism of the Boi de Zabumba style is also corroborated by the use of the friction drum, and the organization of the rhythmic 
material. Unlike in Samba and other carnavalistic manifestations in which this drum is referred to as Cuica ${ }^{(23)}$, but in the Bumbameu-Boi it is known as Tambor Onça

\section{2. Costumes}

The designs and materials used in costumes worn by dancers, musicians, and special characters who compose a Bumba-meu-Boi troupe constitute a significant stylistic distinction among ethnic groups in the region. There are several elements common to all the styles but certain features reflect ethnic peculiarities of a troupe.

There are several types of hats worn in the African style of Bumba-meu-Boi, but this style is best identified with the largest hat worn by the dancers. This hat is made of the inside of a young babaçu of the palm tree family branch (Photo 3), sewn together in a regular top-hat shape and reenforced with wire. The hat is covered with ribbons which hang from the roap center all around the hat leaving a space of about ten centimeters in front for the face. This interval is secured by a dome-like additional piece sewn to the hat and adomed with geometric patterns, star, etc., as desired by the owner (Photo 4).

Hats worn by other dancers and the Zabumba players are made from the common regional straw hats covered with black velour cloth and decorated again with designs according to individual preference, elaborated with colorful glass beads. Still another type os hat is found in the African style of Bumba-meu-Boi. This is a straw hat to which is sewn a dome-like front piece on which are depicted motifs in colorful glass beads. The back of the hat is covered with hanging ribbons from the top center of the hat to the individual's thighs.

There are some feathers in the African style of Bumba-meuBoi and these are worn by the Indian characters in the drama. Their hats are adorned with a small amount of feathers, but the bulk of hats for little Indians are made of cardboard covered with glossy, colorful paper and topped with synthetic rafias. According to Mr. 
Laurentino ${ }^{(24)}$, these synthetic materials have been infiltrating the Bumba-meu-Boi because the authentic materials are becoming scarce and hard to find. In the case of the feathers, for example, the Ema Austriche bird has been declared an endangered species by the government and can no longer be killed for its feathers. As a result, feathers used today for Indians, especially by troupes in the capital city come from different birds.

The peitoral blouse worn by member of the African style of Bumba-meu-Boi is like a cape. Its normal size streches from the neck line to mid foream, extending two to three centimeters lower in front and back. The hem is finished with glass beads. The saiote skirt, however, is made of one single piece of cloth. Both the saiote and the peitoral are made of black velour cloth hemmed with glass beads and decorated with flowers and other motifs in glass beads. Underneath the skirt and the blouse are worn a white long-sleeved shirt, red pants and black shoes covered with white spats (Illustration 2).

\section{3. Choreography}

- The third category of stylistic distinction is the choreography which includes dance steps and the presentation format. Beginning with the latter consideration, each Boi style has adopted specific formation of the dancing during sections of the drama known as Cordão. In the Boi de Zabumba style dance in circle moving in a counter clockwise motion while the accompanying ensemble remains stationary outside of the circle. The Zabumba dance reflects the dance movements of the Tambor de Crioulo with its gingas characteristic of African dances that have survived in Brazil in conjunction with the religion.

\section{Summary and Conclusions}

The analysis of the components of the Bumba-meu-Boi provides a framework for the quest of stylistic creations from which emerge stylistic distinctions. Each style is derived from interaction 
of the legend, which is often maintained as the unifying element of the expression, with features derived from extrinsic forces, usually the culturo-racial baxkgrounds of their participants. In the course of the analysis it became evident that such stylistic elements as the musical instruments, costumes designs, and dance choreography are strongly influenced by, if they do not derive their basic structure from, the three basic racial groups which first interacted at the creation of the Brazilian society. On the one hand, strong indigenous (Indian) influences cannot be overlooked in the Boi de Matraca style, from its prominant musical instrument - Matraca, its metronomic meter pulse, to the predominance of feathers as part of its costume design, decoration, and the choreography patterns of the dance steps which bring to mind Indian dance steps often witnessed at pow-wow events. The African influence can surely be detected in the Zabumba style in the morphological structure of the drum by the same name and by the heavy sounding strokes and rhythmic patterns produced on this drum. Further African presence can be still detected in the dance style of the Boi de Zabumba style which contains gingas similar to those of Tambor de Crioulo dance, with its periodical spins. This is how Jeovah Silva Franca expresses the Africansess of the style: "... it is marked by the presence of the rumbling of the rustic percussion, profoundly felt by its followers like a distant echo of African drum beats heard at night in the houses-of-mina... "(25) The European influence is apparent in the Boi de Orquestra through musical instruments and dance movements.

\section{NOTES}

1) FROBENIUS, Leo. "The Origin of African Civilization", in Smithsonian Institution Annual REport 1898; see also G. Elliot SMITH, In the Begginning; the Origin of Civilization, pp. 20-31.

2) Grupo de Trabajo. "The Study if African Music Contribution to Latin America and the Caribbean: A Methodological Guideline". The World of Music 3 (1990): 103.

3) lbid., p. 103. 
4) "Africanisms in African-America Music", in Joseph E. HOLLOWAY, ed. Africanisms in America Culture, p. 205. See also Kwabena NKETIA, "African Roots of Music in the Americas: An African View", in Report of the 12th Congress, London, American Musicological Society (1981): 82-88.

5) MELO, Guilherme de. A Mísica no Brasil, p. 59.

6) QUEIROZ, 1973: 158.

7) RAMOS, Arthur. O Folclore Negro do Brasil, pp. 115-116.

8) VIEIRA FILHO, Domingos, "Bumba-meu-Boi do Maranhão". Brasil Açucareiro, XXXVI (LXXII, n ${ }^{\circ}$ 2, Agosto de 1968): 102.

9) Ibidem, pp. 102-103.

10) At the last presentation of the year, the shaman's magic does not work and the ox is dissected and its meat symbolically distributed among those present (participants and audience). This version of the legend was told by the founder and leader of the "Rei da União" group, Mr. José Vale and his colleagues.

11) Jomar MORAES, 1986.

12) GAMA, Lopes. "A Estultice do Bumba-meu-Boi". O Carapuceiro n ${ }^{\circ} 2$ (11 de Janeiro de 1840).

13) O Imparcial (15 de Junho de 1861).

14) The Antropology of Music, p. 190.

15) "The social Role of African Music". African Affairs 53:234-41.

16) FALCÃO, s.d: 19.

17) SACRAMENTO, 1868:7.

18) SANTOS, 1971:14.

19) A revolution led by Manuel Francisco dos Anjos Ferreira (known as Balião) from 1831 and was ended in the district of Caxias, Maranhão, in 1846 by the national army under the command of Luís Alves de Lima e Silva. De Lima e Silva was then given the notle title of Duc of Caxias by President Vicente Pires de Camargo, and was immortalized as the Patron of the Brazilian armed forces, after his suceessful campaign in the Paraguaian war; see also SERRA, Astolfo, $A$ Balaiada.

20) VIEIRA FILHO, 1974:60.

21) VIEIRA FILHO, 1974.

22) EXHEZONA, W. W. Nigerian Musical Instruments, p. 125.

23) For the discussion of the origin of the Cuica its uses in Africa and Brazil, sec Kazadi wu MUKUNA, Contribuiçāo Bantu...

24) Interviewed in São Luís, Maranhão. December 1982.

25) See FRANCA, 1981:47. 


\section{SELECTED BIBLIOGRAPHY}

BRANCO, R. P. Castelo. A Civilização do Couro. Teresina, Departamentu Estadual de Imprensa e Propaganda, 1942.

CASCUDO, Luís da Câmara. "Bumba-meu-Boi". In Dicionário do Folclore Brasileiro. 2a. ed., Rio de Janeiro, Instituto Nacional do Livro, 1962.

ECHEZONA, W.W.. Nigerian Musical Instruments: A Definitive Catalogue. Lansing, The Apollo Publishers, 1981.

FALCÃO, Cyro. Bumba-meu-Boi do Maranhão. São Luís, Universidade Federal do Maranhão, s.d.

FERRETTI, Sérgio Figueiredo (ed.). Tambor de Crioula: Ritual e Espetáculo. São Luís, SIOGE, 1979.

FRANCA, Jeovah Silva. "O Meu Bumba-meu-Boi". Cultura Popular. (Julho, 1981):37-50.

FROBENIUS, Leo. "The Origin of African Civilization", in Smithsonian Institution Annual Report, 1898.

GAMA, Padre Lopes. "A Estultice do Bumba-meu-Boi". O Carapuceiro, $n^{\circ} 2$ (11 de Janeiro de 1840).

GOTTHEIM, Vivian I. "Bumba-meu-Boi: A Musical Play from Maranhão". The World of Music, XXX, $\mathrm{n}^{\circ} 2$ (1988).

GOULART, J. A. Brasil do Boi e do Couro, vo. I \& II. Rio de Janciro, Ed. GDR, 1966.

GRUPO de Trabajo. "The Study of African Musical Contribution to Latin America and the Caribbean: A Methodological Guideline". The World of Music, 3(1990): 103-104.

KUBIK, Gerhard. Angolan Traits in Black Music, Games and Dances of Brazil: A Study of African Cultural Extensions Overseas. Lisboa, Junta de Investigações Científicas do Ultramar, 1979.

MAULTSBY, Portia. "Africanism in African-American Music", in Joseph E. HOLLOWAY (ed.), Africanisms in American Culture. Bloomington, Indiana University Press, 1990, pp. 185-210.

MUKUNA, Kazadi wa. Contribuição Bantu na Muisica Popular Brasileira. São Paulo, Global Ed., 1979.

. "Bumba-meu-Boi in Maranhào", In Brasilien. Einfuhrung in Musikkulturen Brasiliens. Tiago de Oliveira Pinto, Ed. Mainz, Schott, 1986, pp, 108-120.

."The Ox and the Slave: Bumba-meu-Boi in Ma ranhão". Progres Report in Ethnomusicology (in press).

MELO, Guilherme de. A Música no Brasil. 2a. ed., Rio de Ja neiro, Imprensa Nacional, 1947.

MENEZES, Bruno de. Bumba-meu-Boi. Auto Popular. Belém, 1958. 
MERRIAM, Alan. The Antropology of Music. 7th. ed., Illinois, Northwestern University Press, 1978.

MEYER, Marlyse. "Le Merveilleux dans une Forme de Théátre Populaire Brésilien: le Bumba-meu-Boi". Revue d'Histoire du Théatre. (JanvierMars, 1963):94-101.

NKETIA, Kwabena. "African Roots of Music in the Americas: An African View", in Report of the 12th Congress. London, American Musicological Society, 1981:82-88.

O Imparcial (15 de Junho de 1861). São Luís, Maranhão.

PRADO, Regina de Paula Santos. Todo Ano Tem: as Festas na Estrutura Social Camponesa. Dissertação de Mestrado. Universidade Federal do Rio de Janeiro, 1977.

QUEIROZ, M. I. Pereira de. "O Bumba-meu-Boi, Manifestação de Teatro Popular no Brasil". O Campesinato Brasileiro. Petrópolis, Vozes, 1973.

RAMOS, Arthur. As Culturas Negras no Novo Mundo. Rio de Janeiro, Civilização Brasileira, 1937. O Folclore Negro do Brasil. 2a. ed., Rio de Janeiro, Casa do Estudante do Brasil, 1954.

SACRAMENTO, João Domingos Pereira do. "Chronica Interna". Semanário Maranhense, ano I, ${ }^{\circ} 45$ (Julho, 1868):7-8.

SANTOS, José de Jesus, O Bumba-meu-Boi do Maranhão. São Luís, Gráfica São Paulo, 1971.

TRACY, Hugh, "The Social Role of African Music". African Affairs, 53 (1954):234-41.

VIEIRA FILHO, Domingos. "Bumba-mcu-Boi do Maranhão". Brasil Açucareiro, XXXVI (LXXII, 2, Agosto de 1968): 102-103. . "Folclore do Maranhão". Revvista Maranhense de Cultura, Ano I, no 1 (Jan.-Jun., 1974):45-62.

Kazadi wa Mukuna é Músicólogo e Professor Doutor na Escola de Música da Universidade de Kent, Ohio/EUA. 